Jap. J. Ornithol. 44: 181-194,

\title{
Demography and Lifetime Reproductive Success in the Polygynous Great Reed Warbler
}

\author{
Dennis HASSELQUIST ${ }^{*}$ \\ Department of Animal Ecology, Lund University, \\ Ecology Building, S-223 62 Lund, Sweden.
}

\begin{abstract}
I analysed demographic parameters and lifetime reproductive success in a Swedish population of Great Reed Warblers. The population was followed on a daily basis in 1985-1993 when all breeding Great Reed Warblers were individually marked and $>95 \%$ of the young fledged in the study area were ringed. Between-year breeding site fidelity of adults was relatively high both for males (55\%) and females (51\%), and it seemed not to be affected by previous breeding results. Natal site fidelity was also relatively high as $14 \%$ of the fledglings hatched in the study area returned to breed in subsequent years. Each year, however, about $50 \%$ of the breeders were hatched outside the study area (i.e. immigrants). The production of lifetime recruits was biased so that $17 \%$ of the males and $13 \%$ of the females produced more than $50 \%$ of the recruits in the population. There was no difference in lifetime reproductive success between native birds and immigrants, suggesting that immigrants contributed substantially to the local gene pool. Despite this, effects of non-incestuous inbreeding, measured as lowered hatchability of eggs among broods of genetically more similar pair members, were found in the study population. This may be a result of the dispersal pattern between local Great Reed Warbler populations in Sweden and also a consequence of the short history of these small populations.
\end{abstract}

Key words : Acrocephalus arundinaceus, Dispersal, Inbreeding, Polygyny, Site fidelity.

By analysing demographic parameters, i. e. immigration, emigration, reproduction and survival, it is possible to elucidate how genetical and ecological factors affect the dynamics of a population. There are certain factors that have strong impact on demographic parameters, and thus also on the dynamics of bird populations. Site fidelity (philopatry) and dispersal (i.e. immigration and emigration) affect the size and genetic structure of populations (VAN NOORDWIJK \& Scharloo 1981, Greenwood 1989). Mating systems (Payne 1979, Dyrcz 1988, NEWTON 1989) and alternative reproductive strategies (WETTON et al. 1987, GiBBS et al. 1990) influence reproductive success and its variation among individuals. Survival (life span) of ten have a strong impact on the lifetime reproductive success (CLUTTON-BROCK 1988). To study these "key" factors, that is to estimate demographic parameters, is particularily interesting when trying to predict the future developement of the size and structure of a population, for example in issues like nature conservation and protection of endangered species.

A group of animals that are particularily vulnerable to extinction are species

* Present address : Section of Neurobiology and Behavior, Cornell University,

Seeley G. Mudd Hall, Ithaca, New York 14853-2702, U. S. A. 
with highly fragmented distributions, i.e. species distributed in a meta-population pattern (PIMM 1991). The higher risk of extinction may be caused by constraints on dispersal between local populations, the higher vulnerability to chance events, founder effects and genetic drift, and adverse genetic effects caused by inbreeding (MAY 1973, VAN NoORDWIJK \& SCHARLOo 1981, GREenwood 1989, MaYNARDSMITH 1989). For birds, even though they in general have a large potential for mobility, the risk of extinction may still be high for species with fragmented distribution and small local populations. The reason for this is that the majority of birds tends to be philopatric (BAKER 1978, GREENWOOD 1980, 1989), and that philopatry may be even more pronounced in species specialised for certain habitats, such as wetlands and rare forest habitats.

In Europe, as well as in other parts of the world, marsh habitats and wetlands are under severe pressure from being destroyed, both by pollution and habitat destruction. Even though quite a number of wetland areas have been protected during the last $30-40$ years, the general trend seems to be that marsh habitats are still decreasing in size and numbers. Thus, many wetland birds have experienced severe declines in population size and the distance between local population (i.e. the fragmentation) have increased (e.g. JöNSSON 1990). This may in turn have strong genetical and ecological impact on the structure of local populations. It will also increase the risk of local extinctions and in the long run cause species to become endangered (ANDRÉN 1994).

I have studied the Great Reed Warbler Acrocephalus arundinaceus which breeds in highly productive reed marshes. The study was carried out at lake Kvismaren in South Central Sweden. In the study area, all adults (territorial males and breeding females) have been colourringed and $>95 \%$ of all fledglings ringed in the years 1985-1993 (e.g. BENSCH et al. 1987, BENSCH \& HASSELqUIST 1991a, HaSSELQUIST \& BENSCH 1991, BENSCH 1993, HASSELQUIST 1994). In Sweden the distribution of the Great Reed Warbler can be characterized as a meta population structure with distinctly separated local populations (HOLMBRING 1973, HASSELQUIST 1994). Even though the Great Reed Warbler is a long distance migrant wintering in tropical Africa (CRAMP 1992, Hedenström et al. 1993), it shows a high site fidelity to the previous year's breeding marsh (BENSCH \& HASSELQUIST 1991a). These features of the Great Reed Warbler makes it an interesting object when analysing ecological and genetical consequences caused by a distribution that is fragmented into small local populations. To study this, I estimated demographic parameters of the Great Reed Warbler population breeding at lake Kvismaren.

\section{METHODS}

In northern Europe the Great Reed Warbler inhabits rich eutrophic lakes with scattered reed beds where it breeds from mid April to early August (DYRC2 1977, BeIER 1981, CATCHPOle et. al. 1985, BeNSCH \& HASSElquist 1991a). It is a facultatively polygynous species (URANo 1985, DYRCZ 1986, EzAKI 1990) where the male and the female have a monomorphic plumage. This paper is based on data from a population of Great Reed Warblers at lake Kvismaren $\left(59^{\circ} 10^{\prime} \mathrm{N}, 15^{\circ} 25^{\prime} \mathrm{E}\right)$ in South Central Sweden. Polygynous males in this population attract females sequentially with on average 8 days interval (BENSCH 1993). The pair males are engaged in mate guarding during $20-100 \%$ of the days their female is fertilisable 
(i. e. from pair formation to the end of egg laying; EzAKI 1987, HASSELQUIST \& BENSCH 1991). Males can only attract females when they sing their loud long song (CATCHPOLE 1983, EzAKI 1987, HASSELOQUIST et al. 1993) and are thus prevented from attracting new females to their territories when they are mate guarding (EZAKI 1990, HASSELqUiST \& BENSCH 1991, HASSELQUist 1994). The males help at least their primary female to feed their young (URANO 1990, BENSCH \& HASSELQUIST 1991b, 1994).

The Great Reed Warbler population at Kvismaren have been studied throughout the breeding seasons in 1985 to 1994 . In the present analyses I have concentrated on the territorial males and breeding females in the population in 1987-1991. For these individuals, data on survival and lifetime number of offspring and recruits (i. e. offspring fledged in the study area that returned as adults) have also been included from the seasons 1985-1986 and 1992-1994. This way of analysing the data resulted in different number of investigated fledglings and of fspring recruits for males and females (see Results). All territorial males and breeding females were trapped in mistnets and then marked with individually unique combinations of colour rings. Previously unringed breeding birds were separated into two age classes; one year old or $\geq$ two years old, basically on the same ageing criteria as for the Reed Warbler Acrocephalus scirpaceus (KARLSSON et al. 1988): In the following analyses I have supposed that birds aged as $Z$ two years old were exactly two years old, which in most cases is a correct approximation (see BENSCH 1993, HASSELqUisT 1994). From early May to mid July, daily visits were made to all territories in the study area. At each visit, information was gathered on which song type the males were singing, male mating status and nesting activities. This intensive field work provided precise information on site fidelity, immigration, survival, mating patterns and reproductive success of all individuals in the population.

In the analyses of life span, individuals that were breeding at least once in the study area in 1987-1991 and raised at least one offspring during their lifetime were included. The latter restriction excluded individuals that failed completely with breeding in the study area as these may be more inclined to change breeding site in the next season. Of the Great Reed Warblers included in the lifetime analyses, 3 males (two five years old and one eight years old) and two females (one five and one six years old) were still alive in 1994. In the analyses of lifetime reproductive success and lifetime production of recuits, I included data from all males that possessed a territory in the study area during at least one breeding season in 1987-1991. Lifetime reproductive success was measured as all young that fledged from an individual's nests during its lifetime (data available from 1985 to 1993). In most cases parentage was assigned by DNA fingerprinting. Lifetime production of recruits was measured as all returning offspring (to natal site) that were assigned to a certain parent (in almost all cases on the basis of DNA fingerprinting). Only breeding individuals that produced at least one fledgling during their lifetime was considered in this analysis.

The origin of each of the breeding Great Reed Warblers (territorial males and breeding females) was defined as either native or immigrant. Natives were ringed in the study area (Kvismaren) as nestling or in a few cases as newly fledged juveniles (in the less extensively studied years 1984-1985). Immigrants were hatched outside the study area (i. e. not ringed as nestlings in the study area) and recorded 
for the first time in Kvismaren when one year old or older.

Alternative reproductive strategies such as extra-pair fertilizations by males and egg dumping by females can have large impact on the reproductive output in a population (e.g. GIBBS et al. 1990, Schulze-HAGEN etal. 1993). Thus, it is necessary to carry out DNA fingerprinting and thereby accurately determine genetical parentage when studying the contribution of each individual to the future gene pool. During the breeding seasons of 1987-1991, almost all Great Reed Warbler fledglings produced in Kvismaren ( $>95 \%$ of the broods), as well as their potential parents, were analysed by DNA fingerprinting (HASSELQUIST 1994, BENSCH et al. 1994, HASSELQUIST et al. 1995). This study revealed a low frequency of extra-pair paternity ( $3 \%$ extra-pair young in the population) and no cases of extra-pair maternity (HASSELQUIST et al. 1995). In the prevailing study, all recruits and most fledglings (except for one brood in 1985, 3 broods in 1986, 3 in 1992 and 4 in 1993) that are included in the analysis of lifetime reproductive success had their true (genetical) parents assigned by DNA-fingerprinting. Thus, these data should give a firm basis for investigating each individual's contribution to the local gene pool.

For statistical analyses I used SYSTAT (WILKINSON 1990) and methods described in SOKAL \& ROHLF (1981).

\section{RESULTS}

1) Site fidelity and immigration

Breeding site fidelity of adult Great Reed Warblers, i. e. the proportion of adults that returned to Kvismaren in subsequent years, was on average $51 \%$ for the females and $55 \%$ for the males (Table 1). There was no significant difference in the return rate between the sexes $\left(F_{(1,10)}=0.13\right.$, n. s., ANOVA on arcsin transformed values). There was a rather high variation in breeding site fidelity between years (males, range $=34-93 \%$; females, range $=18-82 \%$ ). The natal site fidelity, i. e. mean proportion of Great Reed Warblers that were hatched in Kvismaren in one year and returned there in a subsequent year, was $14 \%$ (Table 1).

The between-year return rates of adult males and females (viz. breeders in the study area the previous year) were not correlated $\left(r_{s}=0.27, n=9\right.$, n. s.). However, note that the return rates from the breeding season 1987 were exceptionally high for both sexes (see Table 1). The between-year return rates of adult males and one year old birds (i. e. birds fledged in the study area the previous year) were not correlated $\left(r_{s}=0.04, n=9, \mathrm{n}\right.$. s.). The between-year return rates of adult females and one year old birds tended to be negatively correlated $\left(r_{s}=-0.61, n=9, P<\right.$ $0.10)$.

The probability of returning year ${ }_{i+1}$ seemed to be unaffected by the bird's breeding result the previous year $\left(\right.$ year $_{i}$ ), for females there was no difference between successful breeders year ${ }_{i+1}(\bar{x}=52 \%$ returned; Table 1$)$ and those that failed breeding year ${ }_{1}\left(\bar{x}=58 \%\right.$ returned; $\left(F_{(1,10)}=0.10\right.$, n. s., ANOVA on arcsin transformed values). The same was true for males; males that bred successfully year $_{i}(\bar{x}=62 \%$ returned; Table 1$)$ did not have a higher return rate year $r_{i}+1$ than males that failed with breeding in year ${ }_{i}\left(\bar{x}=46 \%\right.$ returned; $\left(F_{(1,10)}=0.52\right.$, n. s., ANOVA on arcsin transformed values).

To get an overall view of the genetic composition of the Great Reed Warbler 
Table 1. Natal and breeding site fidelity of Great Reed Warblers at Kvismaren in 1988-1993. Individuals are grouped on the basis of their breeding history in year $r_{i}$ and values given are the percentage of those present in year $r_{i}$ that returned the subsequent year $\left(\right.$ year $\left._{i+1}\right)$.

\begin{tabular}{|c|c|c|c|c|c|c|c|}
\hline \multirow[b]{2}{*}{ Return rate of } & \multicolumn{6}{|c|}{ Year of return $\left(\right.$ year $\left._{i+1}\right)$} & \multirow[b]{2}{*}{$\overline{\mathrm{X}} \pm \mathrm{SD}^{:}$} \\
\hline & $\begin{array}{c}1988 \\
\% \\
(n)\end{array}$ & $\begin{array}{c}1989 \\
\% \\
\text { (n) }\end{array}$ & $\begin{array}{c}1990 \\
\% \\
\text { (n) }\end{array}$ & $\begin{array}{c}1991 \\
\% \\
(n)\end{array}$ & $\begin{array}{c}1992 \\
\% \\
\text { (n) }\end{array}$ & $\begin{array}{c}1993 \\
\% \\
\text { (n) }\end{array}$ & \\
\hline $\begin{array}{l}\text { Territorial males } \\
(n \text { year })\end{array}$ & $\begin{array}{c}93 \\
(14)\end{array}$ & $\begin{array}{c}56 \\
(25)\end{array}$ & $\begin{array}{c}34 \\
(29)\end{array}$ & $\begin{array}{c}54 \\
(24)\end{array}$ & $\begin{array}{c}48 \\
(29)\end{array}$ & $\begin{array}{c}43 \\
(30)\end{array}$ & $55 \pm 20$ \\
\hline Raised young year $r_{i}$ & $\begin{array}{c}90 \\
(10)\end{array}$ & $\begin{array}{c}61 \\
(18)\end{array}$ & $\begin{array}{c}40 \\
(20)\end{array}$ & $\begin{array}{c}56 \\
(18)\end{array}$ & $\begin{array}{c}59 \\
(17)\end{array}$ & $\begin{array}{c}64 \\
(14)\end{array}$ & $62 \pm 16$ \\
\hline Failed breeding year ${ }_{i}$ & $\begin{array}{l}100 \\
(4)\end{array}$ & $\begin{array}{l}43 \\
(7)\end{array}$ & $\begin{array}{l}22 \\
(9)\end{array}$ & $\begin{array}{l}50 \\
(6)\end{array}$ & $\begin{array}{c}33 \\
(12)\end{array}$ & $\begin{array}{c}25 \\
(16)\end{array}$ & $46 \pm 29$ \\
\hline Breeding females ${ }^{\prime}$ & $\begin{array}{c}82 \\
(22)\end{array}$ & $\begin{array}{c}57 \\
(30)\end{array}$ & $\begin{array}{c}54 \\
(35)\end{array}$ & $\begin{array}{c}43 \\
(30)\end{array}$ & $\begin{array}{c}18 \\
(33)\end{array}$ & $\begin{array}{c}54 \\
(26)\end{array}$ & $51 \pm 21$ \\
\hline Raised young year $r_{i}$ & $\begin{array}{c}93 \\
(14)\end{array}$ & $\begin{array}{c}56 \\
(27)\end{array}$ & $\begin{array}{c}54 \\
(26)\end{array}$ & $\begin{array}{c}39 \\
(26)\end{array}$ & $\begin{array}{c}18 \\
(22)\end{array}$ & $\begin{array}{c}50 \\
(20)\end{array}$ & $52 \pm 25$ \\
\hline Failed breeding year $_{i}$ & $\begin{array}{l}62 \\
(8)\end{array}$ & $\begin{array}{l}67 \\
(3)\end{array}$ & $\begin{array}{l}56 \\
(9)\end{array}$ & $\begin{array}{l}75 \\
(4)\end{array}$ & $\begin{array}{c}18 \\
(11)\end{array}$ & $\begin{array}{l}67 \\
(6)\end{array}$ & $58 \pm 20$ \\
\hline $\begin{array}{l}\text { Young hatched in the study } \\
\text { area year }{ }_{i}^{*}\end{array}$ & $\begin{array}{c}11 \\
(53)\end{array}$ & $\begin{array}{c}18 \\
(130)\end{array}$ & $\begin{array}{c}8 \\
(130)\end{array}$ & $\begin{array}{c}14 \\
(136)\end{array}$ & $\begin{array}{l}15 \\
(84)\end{array}$ & $\begin{array}{c}15 \\
(89)\end{array}$ & $14 \pm 4$ \\
\hline
\end{tabular}

'Excluding two unringed females (one breeding in 1988 and one in 1989), and 6 and 7 females originating from another population that were introduced to the study area in 1989 and 1990 , respectively.

${ }^{\ddagger}$ Arithmetic mean and standard deviation for the six between-year return rates.

*Excluding 36 young raised from true second broods in 1988. This was the only year when true second broods resulted in fledglings, however none of these young were recorded as adults. 1 therefore omitted these broods from the analyses.

population at Kvismaren, I investigated the annual proportions of breeders that were hatched outside the study area (immigrants) or recruits hatched in the study area (natives), respectively. Each year, on average $47 \%$ of the male breeders were natives and $53 \%$ immigrants $\left(F_{(1,8)}=0.46\right.$, n. s.; ANOVAs on arcsin transformed values; see Table 2), and among female breeders $54 \%$ were natives and $46 \%$ immigrants $\left(F_{(1,8)}=3.62, P=0.09\right.$; ANOVAs on arcsin transformed values; see Table 2). There was no difference in the proportion of successful breeders (producing at least one offspring during a breeding season) between immigrants and natives (males, $\left(F_{(1,8)}=1.1\right.$, n. s.; females, $F_{(1,8)}=0.02$, n. s.; ANOVAs on arcsin transformed values; see Table 2). Similarily, there was no difference in the proportion of individuals that produced offspring recruits between immigrants and natives (males, $F_{(1,8)}=0.37$, n. s.; females, $F_{(1,8)}=0.25$, n.s.; ANOVAs on arcsin transformed values; see Table 2). Hence, annual reproductive success seemed to be independent of if the breeders were natives or immigrants to the study area.

The mean proportion of new immigrants each year was $27 \%$, out of which $9 \%$ were one year old and $18 \%$ more than 2 years old. 
Table 2. Composition and reproductive success of the Great Reed Warbler population at Kvismaren. Data for individuals that returned to their natal site (natives) and those first recorded as adult immigrants are shown separately. Values given are per cent of population size, per cent of territorial individuals that raised young and per cent of territorial individuals that raised recruits, for each year 1987-1991.

\begin{tabular}{lcccccc}
\hline & 1987 & 1988 & 1989 & 1990 & 1991 & $\overline{\mathrm{X}} \pm \mathrm{SD}$ \\
\hline Males(n) & $(9)$ & $(21)$ & $(27)$ & $(23)$ & $(29)$ & \\
Immigrants (\% of n) & 67 & 67 & 48 & 35 & 48 & $53 \pm 14$ \\
$\quad$ Raised young (\% of Imm.) & 83 & 71 & 46 & 62 & 36 & $60 \pm 19$ \\
$\quad$ Produced recruits (\% of Imm.) & 33 & 64 & 23 & 38 & 21 & $36 \pm 17$ \\
Natives (\% of n) & 33 & 33 & 52 & 65 & 52 & $47 \pm 14$ \\
Raised young (\% of Nat.) & 33 & 86 & 86 & 80 & 80 & $73 \pm 22$ \\
$\quad$ Produced recruits (\% of Nat.) & 33 & 57 & 21 & 40 & 60 & $42 \pm 16$ \\
& & & & & & \\
Females(n) & $(22)$ & $(30)$ & $(36)$ & $(30)$ & $(33)$ & \\
Immigrants (\% of n) & 41 & 53 & 53 & 43 & 42 & $46 \pm 6$ \\
Raised young (\% of Imm.) & 56 & 88 & 84 & 85 & 64 & $75 \pm 14$ \\
$\quad$ Produced recruits (\% of Imm.) & 11 & 56 & 26 & 46 & 20 & $32 \pm 19$ \\
Natives (\% of n) & 59 & 47 & 47 & 57 & 58 & $54 \pm 6$ \\
Raised young (\% of Nat.) & 77 & 94 & 53 & 88 & 68 & $76 \pm 16$ \\
Produced recruits (\% of Nat.) & 23 & 71 & 12 & 35 & 53 & $39 \pm 24$ \\
\hline
\end{tabular}
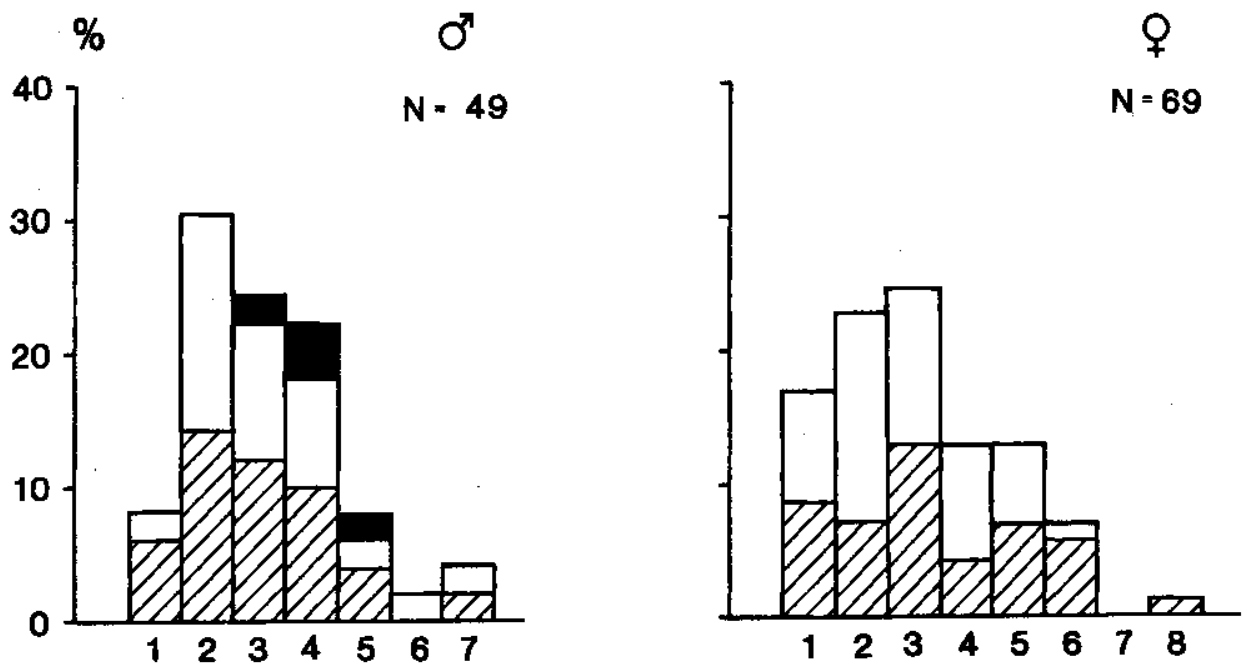

Life span (years)

Fig. 1. Histogram showing life span of Great Reed Warbler males and females that were breeding in Kvismaren 1987-1991. Hatched bars are breeders that were native to Kvismaren, white bars immigrants to Kvismaren, and black bars breeders whose origin were not known. 
2) Survival

The median life span for both males and females in the population was 3 years (males, $n=49$; females, $n=69$ ). The oldest males (two individuals) reached an age of 7 years (Fig. 1a) and the oldest female an age of 8 years (Fig. 1b). There was no significant difference in survival, measured as life span, either for males nor females hatched in the study area as compared to immigrants (males, $U_{2,20}=261$, n. s.; females, $U_{33,36}=691, P=0.23$.).

\section{3) Lifetime reproductive success}

Male lifetime reproductive success was biased so that 11 males (17\%) raised $51 \%$ of the young ( $n=673$ young) that were produced in the population during the study period (Fig. 2a). Sixteen per cent of the territorial males did not raise any young. The mean lifetime reproduction per male was 10.5 young ( $\mathrm{SD}=11.5, n=64$ ). There was no difference in the lifetime reproductive success for native males $(\bar{x}$ $=11.5, \mathrm{SD}=12.5, n=28)$ in comparison with immigrant males $(\bar{x}=8.8, \mathrm{SD}=10.0$, $n=30 ; t=0.92$, df $=56$, n. s.).

The mean lifetime reproductive success for the females in the study population was 7.7 young ( $S D=7.3, n=82$ ). Also for the females, the lifetime reproductive success was rather biased so that 16 individuals (20\%) produced more than $50 \%$ (317 out of 633) of the young in the population (Fig. 2b). 15\% of the females that made at least one breeding attempt did not fledge any young. There was no difference in lifetime reproduction for native females $(\bar{x}=8.6, \mathrm{SD}=8.8, n=40)$ as compared with immigrant females $(\bar{x}=6.9, \mathrm{SD}=5.4, n=42 ; t=1.1, \mathrm{df}=80$, n. s.).

4) Lifetime production of offspring recruits
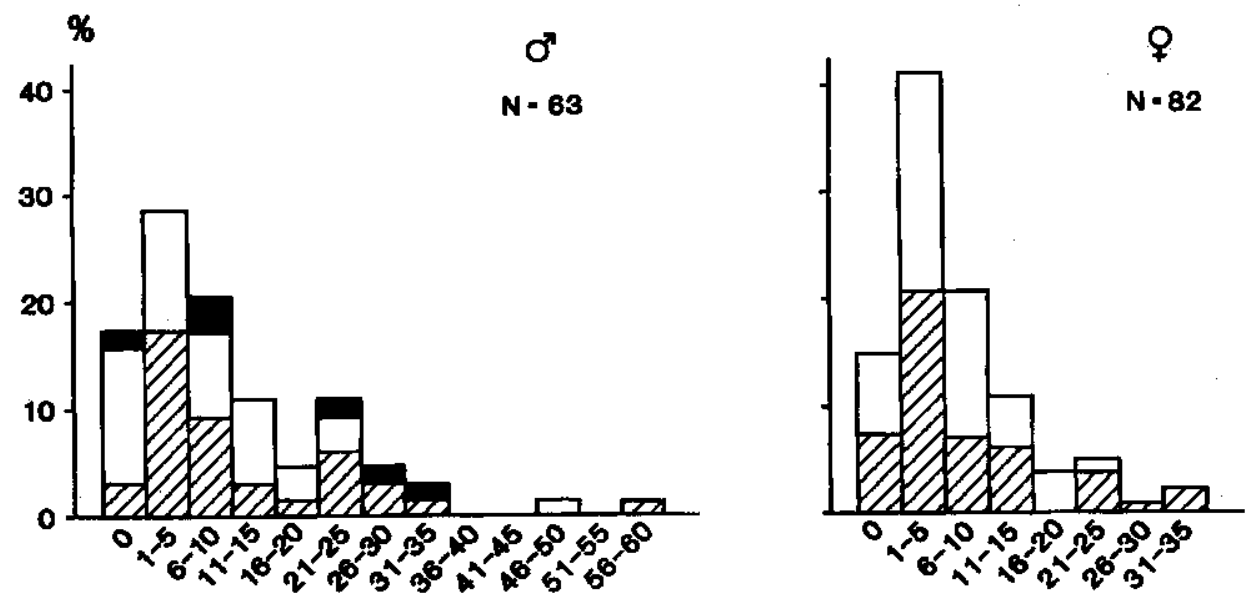

\section{Lifetime number of offspring}

Fig. 2. Histogram showing lifetime reproductive success (number of fledglings) of Great Reed Warbler males and females that were breeding in Kvismaren 1987-1991. Hatched bars are breeders that were native to Kvismaren, white bars immigrants to Kvismaren, and black bars breeders whose origin were not known. 

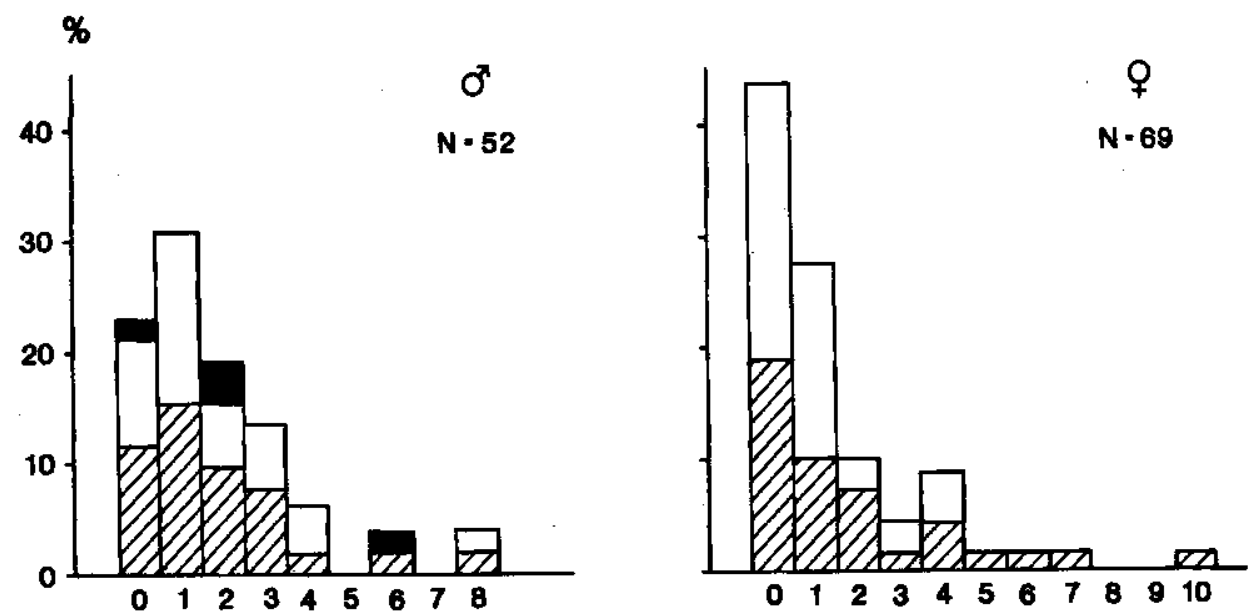

\section{Lifetime number of recruits}

Fig. 3. Histogram showing the number of lifetime recruits (i. e. offspring returning as breeders to their natal site) for Great Reed Warbler males and females that were breeding in Kvismaren 1987-1991. Hatched bars are breeders that were native to Kvismaren, white bars immigrants to Kvismaren, and black bars breeders whose origin were not known.

The mean lifetime production of offspring recruits for males was 1.86 young ( $\mathrm{SD}=1.91, n=52$ males that produced at least one fledgling; Fig. $3 \mathrm{a}$ ). The distribution of male number of lifetime recruits was biased; 10 males (17\%) produced $51 \%$ ( 49 out of 97 ) of the recruits. When looking at the number of lifetime recruits there was no difference between native males $(\bar{x}=1.85, \mathrm{SD}=1.91$, $n=26)$ and immigrant males ( $\bar{x}=1.77, \mathrm{SD}=1.88, n=22 ; t=0.13, \mathrm{df}=46, \mathrm{n} . \mathrm{s}$.$) .$

For females, the mean number of lifetime recruits was 1.4 young $(\mathrm{SD}=1.9, n$ $=69$ ). Nine females (13\%) produced $51 \%$ (48 out of 94 ) of all recruits originating from the study population (Fig. $3 \mathrm{~b}$ ). This was not significantly different from the distribution of the males'production of recruits $\left(\mathrm{X}_{(1)}^{2}=1.65\right.$, n.s.). There was a tendency that native females $(\bar{x}=1.8, \mathrm{SD}=2.4, n=33)$ raised more lifetime recruits than immigrant females $(\bar{x}=0.94, \mathrm{SD}=1.24, n=36 ; t=1.9, \mathrm{df}=67, P$ $=0.06$ ).

To see if natal site fidelity had any effect on an individual's relative production of recruits, I analysed the relationship between site fidelity and the lifetime number of produced recruits when the effect of lifetime number of offspring was controlled for in a multiple regression. For the males there was no significant effect of natal site fidelity $(P=0.99)$ on the number of lifetime recruits when the number of fledged offspring $(P<0.001)$ was partialled out. The same was true for the females (natal site fidelity, $P=0.47$; number of fledged offspring, $P<0.001$ ). Thus, there was no effect of hatching site on the relative production of recruits that returned to the study area, either for males nor females. 


\section{DISCUSSION}

\section{1) Demography}

In the Great Reed Warbler we found no differences between males native to Kvismaren and immigrant males in any of the reproductive parameters (number of fledged young and number of recruits; Table 2). For females there was a tendency that natives had a higher lifetime production of offspring recruits than immigrants. There was no difference in life span between natives and immigrants, either for males nor females (Fig. 1a and 1b). Hence, these data suggest that Great Reed Warblers that are immigrants to the study area contribute substantial new genetic material to the local gene pool. This pattern differs from that found in an empirical study of another North European passerine, the Collard Flycatcher Ficedula albicollis, where individuals that changed their breeding site between seasons experienced lower reproductive output (PÄRT 1991).

Successful breeding in one year did not result in a higher probability of returning the next year, neither for male nor female Great Reed Warblers (Table 1). It is commonly found that successful breeders have higher between-year return rate to their previous year's breeding site than individuals that failed to raise of $\mathrm{spring}$ (NoLAN 1978, HARVEY et al. 1979), suggesting that successful breeders benefit from site fidelity. In the Great Reed Warbler that inhabits highly productive reed beds which in Sweden are sparsely distributed in small local populations (Holmbring 1973, BENSCH et al. 1989), also unsuccessful breeders may benefit from showing high site fidelity. By returning to the previous year's breeding site Great Reed Warblers end up in a suitable breeding habitat without loosing time searching for a new suitable site. Moreover, site fidelity is even more advantageous when, as is the case for the males in the studied population of Great Reed Warblers, pairing and reproductive success seem to be dependent on the attractiveness of their territories (BENSCH \& HASSELQUIST 1991a, 1992). Attractive territories are occupied by older males that arrive relatively earlier in the season (HASSELQUIST 1994) which may suggest that information gathered in year can $_{\mathfrak{1}}$ be used by males when settling in year ${ }_{i+1}$. This pattern would favour site fidelity in all males independent of previous breeding results.

Theoretically, a large variance in reproductive success in a population should result in a decreased genetic variation in the local gene pool. This is likely to be pronounced in polygynous species where males of ten show a large variation in reproductive success (e.g. ORIANS \& BELETSKY 1989). When analysing annual reproductive success in the Great Reed Warbler, males seemed to have a large variance in reproductive success (CATCHPOLE et al. 1985, HASSELQUIST 1994), both in an intraspecific comparison with the females and when comparing with monogamous species. However, when analysing lifetime data, male and female Great Reed Warblers had a similarily large variance in reproductive and recruitment success (see Fig. 2 and 3). Thus, the increase in the genetic variation in the local gene pool due to immigration might be retarded by a disproportionately large contribution of genes from a limited number of highly successful breeders.

\section{2) Inbreeding}

High breeding and natal site fidelity observed in this population can have negative genetic effects for individuals as well as for populations (GREENWOOD et 
al. 1978, vaN NoORDWIJK \& SCharloo 1981, RAlls et al. 1986, WildT et al. 1987). The classical explanation for this is that the probability for matings between genetically related individuals (i.e. incestuous inbreeding) increases in such a population. Incestuous inbreeding increases the risk for recessive genes with negative effects on viability to become homozygous in an individual, resulting in lowered survival and reproduction for the individual carrying these genes (vaN NOORDWIJK \& VAN BALEN 1988). In the study population of Great Reed Warblers the closest related individuals that have been engaged in a pair bond were first cousins ( $\mathrm{r}=0.125$; BENSCH et al. 1994).

In a small population with limited gene flow also non-incestuous inbreeding (i.e. negative effects due to matings between unrelated individuals that are genetically similar; BENSCH et al. 1994) may occur. In the Great Reed Warbler population at Kvismaren, we have found a negative effect of genetic similarity between parents on the proportion of eggs that hatched in their clutches (BENSCH et al. 1994). Genetic similarity was measured as the proportion of DNA fingerprint bands that the pair mates had in common (BENSCH et al. 1994). The occurrence of nonincestuous inbreeding may be a result of small population sizes and repeated population bottlenecks of the Great Reed Warbler population breeding in Sweden (HolmBRING 1973, BeNSCH 1993, BENSCH et al. 1994). The rather high adult survival (Fig. 1) and biased lifetime reproductive output (Fig. 2 and 3), together with a rather high natal and breeding site fidelity (Table 1), are also factors that may have contributed to keep the variation in the local gene pool at a low level.

On the other hand, among the birds breeding in the local population each year on average $49 \%$ were immigrants (Table 1). Moreover, the average lifetime reproductive success of immigrants and natives did not differ (Table 2). These factors may have counteracted the prevalence of inbreeding. Theoretically, a rather low immigration rate of about one individual per generation would be enough to counteract local differentiation (GALL 1987) and thus the occurrence of inbreeding. In the studied Great Reed Warbler population, with an annual effective population size of reproducing individuals $(\mathrm{N})$ of about 9-19 males and 16-27 females, the critical immigration rate that would compensate inbreeding by random drift (1/ $\mathrm{Nm}+1 / \mathrm{Nf}$; GaLl 1987$)$ would be $1 / 25-1 / 45(2-4 \%)$. In the Great Reed Warbler the yearly immigration rate was about $25 \%$ of which on average $60-75 \%$ produced young, suggesting an effective immigration rate of $15-20 \%$. These values are $4-10$ times higher than the critical immigration rate suggesting that immigration relatively rapidly would increase the genetic variation in the local gene pool. However, immigration may have a less marked effect on the variance of the gene pool if immigrants and native birds have high genetic similarity. As a matter of fact, both the breeding history of the Great Reed Warbler in Sweden and the pattern of dispersal between local populations within Sweden suggest that this may be the case. The Great Reed Warbler colonized Sweden some 30 years ago, and the whole population consisted of less than 10 pairs in the late 1960th (HoLmBRING 1973). At predent the Swedish population consists of about 500-600 pairs (BENSCH et al. 1989), distributed in a meta-population like pattern with more than $75 \%$ of all pairs restricted to ten local populations isolated by $15-150$ $\mathrm{km}$ of areas that are unsuitable for Great Reed Warblers (Fig. 4). It is not unlikely that these local populations were founded mainly by subsets of the original Swedish Great Reed Warbler population, and thus that the genetic 


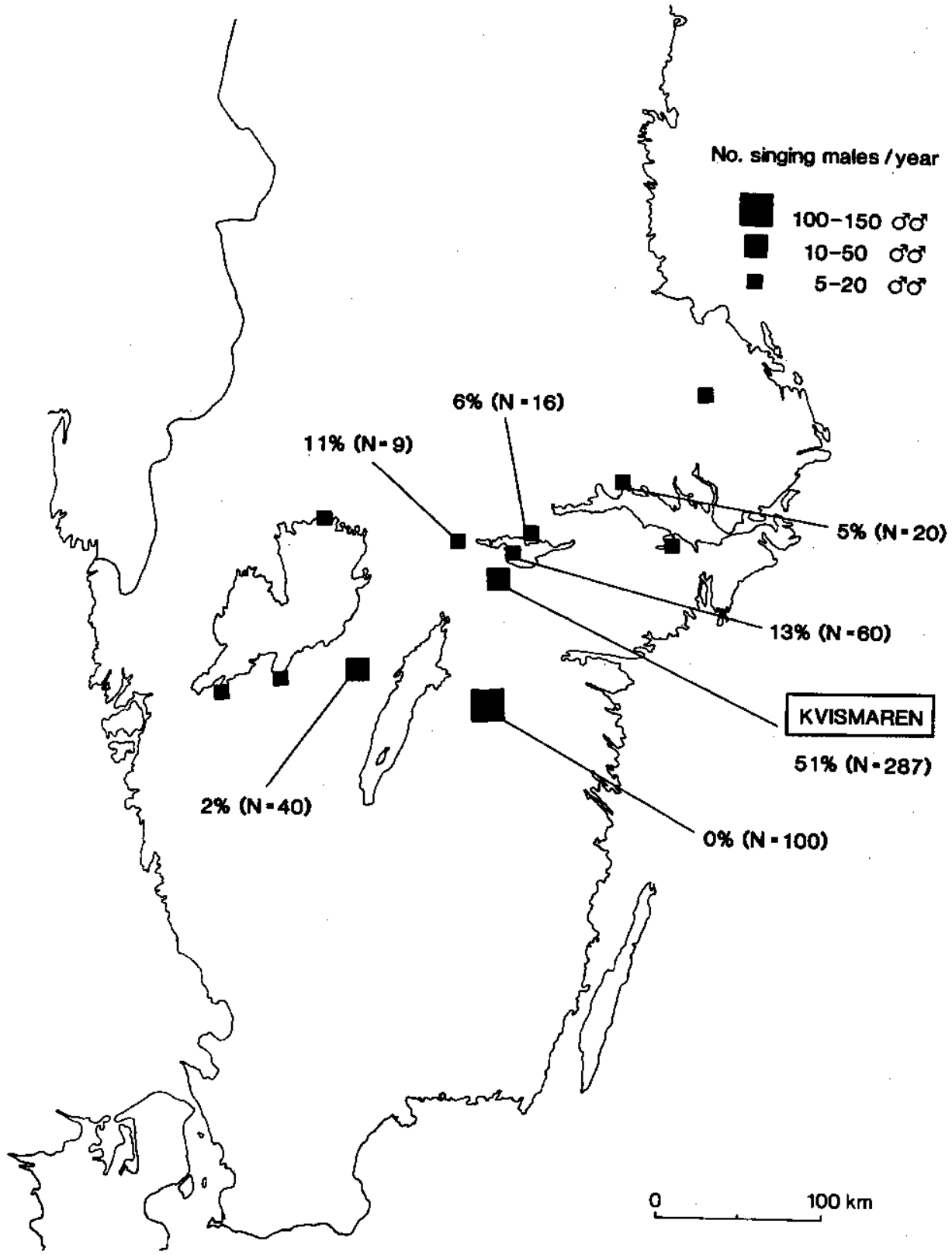

Fig. 4. Map showing the distribution and number of singing (i.e. territorial) Great Reed Warbler males in Sweden in 1990. Natal dispersal is given as the percentage of the total number of investigated adults at each site ( $\mathrm{N}$, including both males and females), that previously were ringed as nestlings at Kvismaren in 1986-1992. 
variation between these local populations still is rather low. Moreover, there seems to be more exchange of individuals between closely situated local populations (Fig. 4). Because Great Reed Warblers from more closely situated local populations seem to have higher genetic similarity (BENSCH et al. 1994), this may counteract the increase of genetic variation suggested by the rate of immigration to the local population at Kvismaren.

Throughout this study, Staffan BENSCH has been an invaluable part of all the field work and he also gave constructive comments on the manuscript. I am most grateful to several persons that helped with field work for long time periods, Bo NiElsen, Peter Frodin, Fredrik HaAs, Mikael Haraldsson, Ulf OtTosson, and Anders KVIST. Torbjörn vON SCHANTZ provided us with facilities to carry out DNA fingerprinting and learned us how to do it. Kerstin PERSSON and Åsa LANGEFORS helped with the lab work. The field study was funded by grants from; the Royal Swedish Academy of Sciences (J.A. Ahlstrands found, Hierta-Retzius fonder), Elis Wides Foundation, Lund University Travel Funds and the Lund Animal Protection Society (Lunds Djurskyddsfond). The lab work was funded by; the Swedish Natural Research Council (NFR), the Swedish Council for Planning and Coordination of Research (FRN), the National Swedish Environment Protection Board (SNV) the Carl Trygger Foundation for Scientific Research, the Carl Tesdorpf Foundation, the Maja and Erik Lindquist Research Foundation and the Crafoord Foundation in Lund (to Torbjörn von ScHANTZ. This is report no. 86 from Kvismare Bird Observatory.

\section{REFERENCES}

ANDRÉN, H., 1994. Effects of habitat fragmentation on birds and mammals in landscapes with different proportions of suitable habitat; a review. Oikos $71: 355-366$.

BAKER, R.R., 1978. The evolutionary ecology of animal migration. Hodder \& Stoughton, London.

BewEk, J., 1981. Untersuchungen an Drossel- und Teichrohrsänger Acrocephalus arundinaceus, A. scirpaceus: Bestandsentwicklung, Brutbiologie, Ökologi. J. Orn. 122 : $209-230$.

BENSCH, S., 1993. Costs, benefits and strategies for females in a polygynous mating system: a study on the Great Reed Warbler. PhD thesis, Lund University, Lund, Sweden.

Bensch, S., Eriksson, N. \& Hasselquist, D., 1987. (Studies of the ecology of the Great Reed Warbler at lake Kvismaren, in Sweden). Vår Fågelvärld $46: 89-92$. (In Swedish).

Bensch, S., Gezelius, L. \& Hasselquist, D., 1989. (How many Great Reed Warblers breed in Tåkern). Vingspegeln $9: 51-59$. (In Swedish).

BensCH, S., \& HASSELQUIST, D., 1991a. Territory infidelity in the polygynous Great Reed Warbler Acrocephalus arundinaceus; the effect of variation in territory attractiveness. J. Anim. Ecol. 60 : 857-871.

BENSCH, S., \& Hasselquist, D., 1991b. Nest predation lowers the polygyny threshold: a new compensation model. Am. Nat. 138 : 1297-1306.

BENSCH, S., \& HASSELQUIST, D., 1992. Evidence for active female choice in a polygynous warbler. Animal Behaviour $44: 301-311$.

BENSCH, S., \& HASSELQUIST, D., 1994. Higher rate of nest loss among primary than secondary females: infanticide in the Great Reed Warbler? Behav. Ecol. Sociobiol. 35 : 309-317. 
Bensch, S., \& Hasseiquist, D. \& von Schantz, T., 1994. Genetic similarity between parents predicts hatching failure: non-incestuous inbreeding in the polygynous Great Reed Warbler? Evolution 48 : 317-326.

Catchpole, C. K., 1983. Variation in the song of the Great Reed Warbler Acrocephalus arundinaceus in relation to mate attraction and territorial defence. Anim. Behav. $31: 1217-1225$.

Catchpole, C. K., Leisler, B. \& Winkler, H., 1985. Polygyny in the Great Reed Warbler Acrocephalus arundinaceus: a possible case of deception. Behav. Ecol. Sociobiol. $16: 285-291$.

Clutton-Brock, T.H., 1988. Reproductive success. University of Chicago Press, Chicago and London.

Cramp, S., 1992. Handbook of the Birds of Europe, the Middle East and North Africa. Vol. VI, Warblers. Oxford, Oxford University Press.

DYrCz, A., 1977. Polygamy and breeding success among Great Reed Warblers Acrocephalus arundinaceus at Milicz, Poland. Ibis 119 : 73-77.

DYrcz, A., 1986. Factos affecting facultative polygyny and breeding results in the Great Reed Warbler Acrocephalus arundinaceus. J. Orn. 127 : 447-461.

Dyrcz, A., 1988. Adaptive significance of facultative polygyny in birds. Proc. Int. 100. DO-G Meeting, Current Topics Avian Biol., Bonn: 283-291.

EzAKI, Y., 1987. Male time budgets and recovery of singing rate after pairing in polygamous Great Reed Warblers. Jap. J. Ornithol. $36: 1-11$.

EzAKI, Y., 1990. Female choice and the causes and adaptiveness of polygyny in Great Reed Warblers. J. Anim. Ecol. 59 : 103-119.

GALL, G. A. E., 1987. Inbreeding. RYMAN, N. \& UTTER, I. (eds.) Population genetics and fishery management: 47-87. University of Washington Press, Seattle and London.

Gibes, H. L., Weatherhead, P. J., Boag, P. T., White, B. N., Tabak, L. M. \& Hoysak, D. J., 1990. Realized reproductive success of polygynous Red-Winged Blackbirds revealed by DNA markers. Science $250: 1394-1397$.

Greenwood, P.J., 1980. Mating systems, philopatry and dispersal in birds and mammals. Anim. Behav. $28: 1140-1162$.

GrEENwOOD, P. J., 1989. Inbreeding, philopatry and optimal outbreeding in birds. Cooke, F. \& Buckley, P. A. (eds.) Avian genetics: 207-222. Academic Press, London.

Greenwood, P. J., Harvey, P. H. \& Perrins, C. M., 1978. Inbreeding and dispersal in the Great Tit. Nature 271 : $52-54$.

Harvey, P. H., Greenwood, P. J. \& Perrins, C. M., 1979. Breeding area fidelity of Great Tits (Parus major). J. Anim. Ecol. 48 : 305-313.

Hasselquist, D., 1994. Male attractiveness, mating tactics and realized fitness in the polygynous Great Reed Warbler. PhD thesis, Lund University, Lund, Sweden.

Hasselquist, D. \& BENSCH, S., 1991. Trade-off between mate guarding and mate attraction in the polygynous Great Reed Warbler. Behav. Ecol. Sociobiol. 28:187193.

Hasselquist, D., Bensch, S. \& OTtosson, U., 1993. Diurnal song pattern in the polygynous Great Reed Warbler Acrocephalus arundinaceus. Ornis Suecica $3: 125$ 136.

HASSELQUIST, D., BENSCH, S. \& von SchaNTZ, T., 1995. Low frequency of extra-pair paternity in the polygynous Great Reed Warbler Acrocephalus arundinaceus. Behav. Ecol. 6 : 27-38.

Hedenström, A., BeNsch, S., Hasselquist, D., Lockwood, M. \& OtTosson, U., 1993. Migration, stopover and moult of the Great Reed Warbler Acrocephaus arundinaceus in Ghana, West Africa. Ibis $135: 177-180$.

HoLmBRING, J.A.., 1973. (The Great Reed Warbler Acrocephalus arundinaceus in 
Sweden in 1971, and a review of its earlier status). Vår Fågelvärld $32: 23-31$. (In Swedish with English summary)

Jönsson, P. -E., 1990. The Dunlin Calidris alpina schinzii as a breeding bird in Scania 1990-numbers, hatching success and population trends. Anser 29:261-272. (In Swedish with English summary).

Karlsson, L., Persson, K. \& Walinder, G., 1988. (Ageing of the Reed Warbler Acrocephalus scirpaceus by use of iris colour, tarsus colour and tounge spots). Vår Fågelvärld $47:$ 141-146. (In Swedish with English summary).

MAY, R. M., 1973. Stability and complexity in model ecosystems. Princeton University Press, Princeton, N. J.

MAYNARD-SMith, J., 1989. Evolutionary genetics. Oxford University Press, Oxford.

N.wTton, I., 1989. Lifetime reproduction in birds. Academic Press, London.

Nolan, V. 1978., The ecology and behavior of the Prairie Warbler Dendroica discolor. Ornithological Monographs 31 : 1-595.

Noordwijk, A.J. van \& Balen, J. H. van., 1988. The Great Tit. Clutton-Brock, T. H. (ed.) Reproductive success: 119-135. University of Chicago Press, Chicago and London.

NoordWIJK, A. J. van \& ScharLoo, W., 1981. Inbreeding in an island population of the Great Tit. Evolution $35: 674-688$.

Orians, G. H. \& Beletsky L., 1989. Red-winged Blackbird. Newton, I. (ed.) Lifetime reproduction in birds: 183-197. Academic Press, London.

PAYNe, R. B., 1979. Sexual selection and intersexual differences in variance of breeding success. Am. Nat. $114: 447-466$.

PIMM, S. L., 1991. The balance of nature? University of Chicago Press, Chicago and London.

PÄrT, T., 1991. Philopatry and age as factors influencing reproductive success in the Collared Flycatcher (Ficedula albicollis). $\mathrm{PhD}$ thesis, Uppsala University Uppsala, Sweden.

RaLLS, K., HARVEY, P. H. LyLeS, A. M., 986. Inbreeding in natural populations of birds and mammals. SoulE, M. (ed.) Conservation biology : the science of scarcity and diversity : 35-56. Sinauer, Sunderland, MA.

Schulze-Hagen, K., Swatscek, I., Dyrcz, A. \& Wink, M., 1993. Multiple Vaterschaften in Bruten des Seggenrohrsängers Acrocephalus paludicola: Erste Ergebnisse des DNA-fingerprintings. J. Ornithol. $134: 145-154$.

SoKAL, R.R. \& RohLF, F. J., 1981. Biometry. 2 nd edition. W. H. Freeman \& Company, New York.

Urano, E., 1985. Polygyny and the breeding success of the Great Reed Warbler Acrocephalus arundinaceus. Res. Popul. Ecol. 27 : 393-412.

URANo, E., 1990. Factors affecting the cost of polygynous breeding for female Great Reed Warblers Acrocephalus arundinaceus. Ibis 132 : 584-594.

Wetton, J. H., CARTkR, R. E., Parkin, D. T. \& Walters; D., 1987. Demographic study of a wild House Sparrow population by DNA fingerprinting. Nature 327 : 147-149.

Wildt, D. E., Bush, M., Goodrowe, K. L., PACKer, C. Pusey, A. E., Brown, J. L., JosLrN, P. \& O'BRIEN, S. J., 1987. Reproductive and genetic consequences of founding isolated Lion populations. Nature 329 : 328-331.

WILKINSON, L., 1990. SYSTAT : the system for statistics. SYSTAT Inc., Evanston, Ill.

(Accepted 13 July 1995) 
一夫多妻の第一巣では第二雌の巣よりあ10日早く産卵が始まった（Fig. 1)。

繁殖結果の統計值を Table 1 にまとめた。第二雌の巣立ち雛数は一夫一妻雌よりあ低かったが （相対成功度は0.79）、同時期に一夫一妻だった雌とは有意に異ならなかった（相対成功度は $0.85 ） 。$ 繁殖集団に加わることのできた巣立ち雊の割合は第一雌の雊があっとも高かったが、一夫一妻の雊之 第二雌の雊とでは有意差はなかった。したがって、一夫多妻のいき值モデルを排除することはできな W。

雄の配偶ステータスには年齢が影響し、年長の雄がより高い割合で一夫多妻になる（Fig. 2)。年 齢と雌の配偶ステータスとには有意な相関はなかった（Fig. 3)。雄の最年長記録は11歳、雌は10歳 だった。

雌による配偶者選択における雄の質となわばりの質との相対的な重要性を知るために、29雄（一夫 多妻 4 羽、一夫一妻 22 羽、独身 3 羽) を対象に、判別分析を用いて 3 種類のなわばりの特徴と 11 種類 の雄の特徴（身体的な形質、年齡、さえずりのレパートリー数、攻撃性、ホルモンレベル）を分析し た。一夫多妻を予測するもっとも有効な基準となるのは、開水域に面したョシ原の縁が長いこと、攻 撃性が弱いこと、さえずりのレパートリー数が多いことであった（Table 2, Fig. 4 の axis 1)。 第二の判別軸に沿っては 3 群の雄が十分に分離されていないが、この軸は若齢、短い翼と総排泄腔突 起、レパートリー数の少なさおよび黄体形成ホルモン（LH）のレベルが低いことを表している。ヨ シ原の縁の長さは営巣場所としてだけでなく、採食生態上む重要なのかもしれない。一夫多妻雄の攻 撃性の低さは、それらが早い時期に渡来することとテストステロンのレベルの季節的隇退によって説 明できるだろう。

結論は次の 3 点である。（1）一夫多妻が生じることの説明を、以前の論文で支持された「だまし仮 説」に求める必要は必ずしあない。(2) 本調査地は一夫多妻のための生態的条件に関して最適な場所 とは言えないが（不自然に多い魚のために慨供給が抑えられている、一夫多妻の頻度むやや低い、 1 雄とつがう雌数が 2 羽を越えることはほとんどない、雛の餓死がやや頻繁に生じる)、雌による積極 的な配偶者選択を可能にするのには十分な、繁殖条件の予測可能な差異が存在するようだ。（3）雌は 雄の特徴となわばりの質の両方を基に配偶者を選んでおり、雄・なわばり双方の要因には正の相関が ある。

\title{
一夫多妻性のオオヨシキリにおける個体群統計学 と生涯繁殖成功度
}

(Demography and lifetime reproductive success in the polygynous Great Reed Warbler. 44 : 181-194)

\author{
HASSELQUIST, D. * \\ Department of Ecology, Animal Ecology, Ecology Building, \\ S-223 62 Lund, Sweden
}

スウェーデンの Kvismaren 湖で繁殖するオオヨシキリの個体群について、個体群統計学上の種々 の变数と生涯繁殖成功度を分析した。1985-1993年のシーズン中ほぼ毎日調査を行った。全繁殖個体 に個体標識をつけ、巣立った雊の $95 \%$ 以上に足環をつけた。

${ }^{*}$ Present address : Section of Neurobiology and Behavior, Cornel University, Seeley G. Mudd Hall, Ithaca, New York 14853-2702, U.S.A. 
年度を越えて同じ繁殖場所へ戻ってきた成鳥の割合は、雄で55\%、雌で51\%と高かった（Table 1)。 調查地で巣立った雛で、翌年繁殖のために戻ってきたあのの割合も高かった (14\%; Table 1)。あ る年度に繁殖に失敗した個体と成功した個体とで、翌年の帰還率に違いはなかった（Table 1)。每 年の繁殖個体の約 $50 \%$ は、調查地外で巣立ったものだった（Table 2)。平均寿命は雌雄とも 3 年だっ た (Fig. 1 参照)。調查地で生れ調査地に定着した個体と他所で生れて移入してきた個体とで、寿 命に差はなかった。代替繁殖戦略（つがい外交尾や種内托卵）の効果は低かったー1987-1991年に巣 立った雊の $95 \%$ 以上について DNA フィンガープリント法で真の親を同定した結果、つがい外の雄 によって授精されていた㮲は $3 \%$ に過ぎなかった（HASSELQUIST et al. 1995)。生涯に巣立たせた子 の数は、雄親では平均 10.5 羽、雌親では7.7羽だったが、雌雄とも個体差が大きく、次世代の雅の 50 \%を巣立たせたのは繁殖雄の17\%、雌の20\%の個体だった（Fig. 2 参照）。生涯に産み出した、成 鳥として定着できた子の数は、雄親当たり1.86羽、雌親当たり1.4羽だったが、やはり個体差が大き く、成鳥として定着した子の $50 \%$ 以が、17\%の雄、13\%の雌によるものだった（Fig. 3 参照)。 調査地生れの個体と移入個体とで、雅を巣立たせるのに成功したものの割合や子が成鳥として定着で きたものの割合には差はなく（Table 2)、生涯に巣立たせた雊数や成鳥として定着できた子の数に あ差はなかった (Figs. 2-3 参照)。これらの結果は、調査地に移入してきたオオョシキリが地域個 体群への新しい遺伝的素材をむたらすという点で重要な貢献をしていることを示唆する。

調查地の個体群では、 $r \geqq 0.25$ の近親個体間での繁殖例はなく、もっとも近かった 1 例はいとこ同

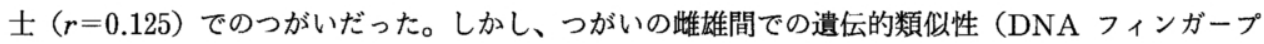
リントのバンドの共有率で測定）と粰化しない卵の割合との間に有意な正の相関が知られている (BENSCH et al. 1994)。これらのデー夕は、調查個体群では近親婚（incest）によらない同型交配 （inbreeding）が起こっていることを強く示唆する。この現象は創始者効果と個体群が小さいことに よって説明されるかむしれない。それに加えて、分散距離が短いという一般的傾向が、近隣個体群間 での大規模な個体の交流をもたらし（Fig. 4)、互いに高い遺伝的類似性をあつことで（BENSCH et al. 1994 参照)、近親婚によらない同型交配を促進してきた可能性むある。

\section{ヨシキリ属における配偶システムの進化}

(The evolution of mating systems in Acrocephalus warblers. 44 : 195-207)

CAtchpole, C. K.

School of Biological Sciences, Royal Holloway, University of London, Egham, Surrey TW20 OEX, U.K.

本論文ではヨシキリ属の配偶システムとその進化の考えられる筋道について概説する。これは LEISLER \& CATCHPOLE (1992) の総説をより新しくしたあのである。前著の発表以降、いくつかの 分野で重要な進歩や新発見があった。とくに DNA フィンガープリント法による最近の研究は従来 の知見に大きな衝撃をむたらしてきた。本論文ではまた、さえずりの進化に関する CATCHPOLE (1980，1987）による初期の研究をより新しいものに改め、さえずりの進化と配偶システムとの関係 について論じる。 